\section{Floriculture and Fundraising: A Public-Student Partnership for Learning Job Readiness}

\author{
Sabine R. Green ${ }^{1}$ and Geno A. Picchioni
}

AdDitional INDEX WORDs. fund raising, floral design, student evaluation tools, silent auction, artist's reception

$\mathrm{T}$ he floriculture industry requires university-trained employees with wide-ranging skills, including hands-on experience, internships, and market knowledge. Retail floristry programs cover a wide range of topics, enabling a student to be ready to work or start his or her own business. Developing college courses that emphasize the retail marketing of agricultural products is becoming increasingly important (Nefstead, 2001). Finding a testing tool to challenge the students to bring all aspects of the course together for a real-world experience is a challenge for the instructor.

Engaging a student in a psychomotor task to reinforce what was learned in part of experiential learning is known as cognitive domain (Newcomb et al., 2004). Instruction that incorporates the presentation of the information combined with a real-world experiential learning (laboratory style) practicum is likely best for teaching applied skills to novices (Duncan, 1996). Mexal et al. (2004) states that alumni may become interested with well-defined, modest programs that are most familiar to them and that alumni and emeriti from the specific program or department may respond positively to targeted requests. He notes that this interest can then be used to establish scholarships and endowments.

We have developed a cumulative final exam in practicum format that tests student knowledge on design elements, seasonality, planning, marketing, and customer service skills. Since practicum testing can be costly, we incorporate a public auction to allow bidders to purchase final arrangements.

Department of Plant and Environmental Sciences, New Mexico State University, Las Cruces, NM 88003

This paper was part of the National Floriculture Forum, "Partnerships, Alliances, Brands and Initiatives," held 10-11 Mar. 2011 in Dallas, TX, and hosted by Texas A\&M University

This work was supported by the New Mexico Agricultural Experiment Station.

${ }^{1}$ Corresponding author. E-mail: swhitley@nmsu.edu.
We hypothesized that a bidding audience would appreciate student floral design proficiencies by bidding higher on arrangements that received higher grades. Here, we discuss our findings collected over a 2-year period.

\section{Preparations and final examination format}

Students enrolled in Beginning Floral Evaluation and Design at New Mexico State University (NMSU) are required to participate in a cumulative final exam. The final is a culmination of all concepts learned during the course of the semester. The format for the final exam is nontraditional. Students are expected to create a unique floral design of dried, fresh, or artificial materials of their choice, and present it during a public artist's reception. Additionally, the reception functions as a fundraiser as it allows the public to interact by using a "silent auction" concept to generate funds. Students are encouraged to interact with the attendees to solicit bids in a tasteful, classic customer service manner. Students are not graded on the number of bids they receive or on the amount of money that they bring in from the winning bid. This testing format allowed the students to demonstrate their floral industry product knowledge, basic floral design skills, postharvest knowledge, skills in customer service and interpersonal relations, marketing and advertisement knowledge, and time management.

In addition to the actual floral art, students are required to submit a concept page, advertisement, recipe for the design, and a final portfolio of the planning of their work. The concept page and recipe (number, type, and color of flowers for the arrangement) are submitted one month before the final, to be approved by the instructor. This process encourages timeliness and ensures that the student is preparing for the event. Additionally, it allows the instructor to prepare the fresh flower order for the event. This process mimics the retail floral industry (particularly the special events genre) in that estimates and orders must be placed in time for shipping and product attainment to occur. The student must learn product seasonality to place a valid recipe order. The creation of an advertisement draws upon the marketing curriculum, and the final portfolio would serve as a special event concept presented to a potential client.

The day of the final, students are expected to arrive either in time to create their floral piece before the reception, or arrive with the floral piece in hand, completed. Half of a standard 6-ft-long rectangular table is assigned to each student to create a vignette. The vignette is a focal area that enhances the marketability of a product, such as in retail window displays. The students can choose to turn in requests for vignette items that are in the floriculture inventory (such as drop cloths and pillars) when they turn in their recipe, or they can supply their own items. Students are encouraged to dress appropriately, bringing a feel of professionalism and elegance to the event. Students are graded on all the items. A breakdown of the percentage for each item is presented in Table 1.

During the last 2 years of administering this final exam, data included the grade that was received for the final exam, starting bid, winning (final) bid, and number of bids received. Linear regression analyses were performed to evaluate the relationships between final exam grade and bidding price, grade and number of bids, and final bid price and number of bids.

During finals week of the second year of data collection (Fall semester, 2010), the students were also given

\begin{tabular}{llll}
\hline $\begin{array}{l}\text { Units } \\
\begin{array}{l}\text { To convert U.S. to SI, } \\
\text { multiply by }\end{array}\end{array}$ & U.S. unit & SI unit & $\begin{array}{l}\text { To convert SI to U.S., } \\
\text { multiply by }\end{array}$ \\
\hline 0.3048 & $\mathrm{ft}$ & $\mathrm{m}$ & 3.2808
\end{tabular}


Table 1. Components of the final examination for the class "Beginning Floral Evaluation and Design" (Hort 240 ) and proportion of each component as a percentage of the Hort 240 student's final exam grade. ${ }^{\mathrm{z}}$

\begin{tabular}{lc}
\hline $\begin{array}{l}\text { Examination } \\
\text { component }\end{array}$ & $\begin{array}{c}\text { Proportion of } \\
\text { total grade (\%) }\end{array}$ \\
\hline $\begin{array}{l}\text { Advertisement and } \\
\text { marketing page }\end{array}$ & 10 \\
$\begin{array}{l}\text { Recipe and concept } \\
\text { page; timeliness }\end{array}$ & 10 \\
$\begin{array}{l}\text { Floral design } \\
\text { Vignette }\end{array}$ & 50 \\
Final portfolio & 10 \\
\hline "Floral designs and vignette graded on mechanics \\
during the reception and photographically docu- \\
mented for further grading at a later date. All other \\
elements graded after the reception.
\end{tabular}

an open-ended questionnaire to anonymously share their thoughts and reflections about the experience. The questionnaire prompted students to explain what they thought they were being tested on, if they ever had a public practicum as a testing strategy before, confidence building, and suggestions. Comments and suggestions were collected to facilitate a more positive experience for undergraduates in the future.

Advertisement of the event included several avenues. Universitywide e-mails were sent, as well as over 200 individual e-mails to past attendees, alumni, emeriti, and donors of the NMSU floriculture program. The departmental and college websites also posted information. Local floral shops and wholesalers were invited and asked to advertise the event, and students were encouraged to invite family and friends. The New Mexico State Florist Association (Roswell, NM) and the West Texas-New Mexico regional Florist Association (Lubbock, TX) were also notified and asked to distribute announcements via e-mail to their membership lists. Additionally, the campus newspaper, radio, and television station provided public service announcements. In the most recent year, social networking sites such as Twitter, MySpace, and Facebook were also used. Data on public attendance of the event was not recorded.

\section{Outcomes}

The final exam grade reflected the proficiency with which a student incorporated all of the floral design elements and concepts learned throughout the semester. The hypothesis (higher bid prices with higher grades) proved to be true in that the final bidding price tended to increase with the grade. The marginal correlation (Fig. 1A) explained 13\% of the variation in final bid price among the arrangements and was limited by sample size $(N=24)$ and by a narrow range of exam scores $(88 \%$ of the students received a grade of 90 or above). While these findings may be revealing to future students in the validation of grading criteria, other factors more important than grade may affect the bidding price.

A somewhat stronger positive correlation was observed between final bidding price and the number of bids received for a given arrangement (Fig. 1B). This indicates that higher-priced arrangements may be more popular to our bidding audience than are the lower-priced arrangements. There were no apparent correlations between grade and starting bid or between grade and number of bids (data not shown).

In the after-exam questionnaire of the second year of the study, one student mentioned having a similar practicum type final that included the public, and in a college setting. No student had previously experienced a fundraising project combined with a final exam, which indicates a uniqueness of our concept. Students likened the event to a science fair or an artist's opening at a gallery or museum. Other comments included the following: it raised my confidence as a floral designer; I felt that I was ready for the real world; I feel more aware of the (floral) industry, and can identify plants readily, walking through a neighborhood; I feel I could get hired and flourish in a (floral) shop if the opportunity arose; and I was encouraged to continue designing.

We found no similar final examination formats reported in the literature. In addition to offsetting teaching costs, this unique studentpublic partnership can serve smallsized academic programs, such as ours, in several ways. Building public awareness increases support and donor clientele. Hosting an annual event helps to create expectation in past attendees. Experiential learning programs such as floriculture should exploit a product that can be offered to
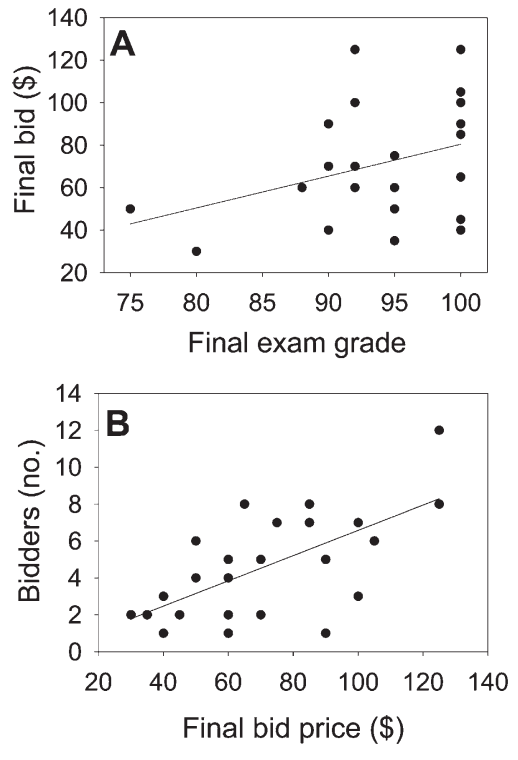

Fig. 1. Relationship between final exam grade for the class "Beginning Floral Evaluation and Design" (Hort 240) and (A) the final bid amount for the silentauction floral-design item submitted by students as their final project in Hort 240 , and (B) between the final bid amount for the silent-auction floraldesign item and number of bidders for the silent auction (2009 and 2010 data combined, $N=24$ students). Regression equations: (A) final bid price $=-69.6+$ 1.5 (final exam grade), $\mathrm{R}^{2}=\mathbf{0 . 1 3}$; $(\mathrm{B})$ number of bids $=-\mathbf{0 . 2 7}+\mathbf{0 . 0 7}$ (final bid price), $\mathrm{R}^{2}=0.41$

the public, which is a by-product of the learning. Allowing public access to "help support a good cause" by purchasing the product is appealing to the general population. If advertised through local and state professional organizations, it creates job opportunities and strengthens collaboration efforts with local industry.

We are familiar with the excellent undergraduate floriculture programs throughout the United States that already have the personnel and resources to put such a concept to use. Programs other than retail floristry or floriculture, such as animal science, agriculture mechanics, arts, theater, and fashion design/merchandizing, could also benefit from similar testing formats.

There has been an outpouring of support for this final examination format-from students, faculty and staff, administration, and the public. Further research is pending to generate larger sample sizes that could reveal significant learning outcomes for 


\section{Symposium Proceedings}

students and consumer preferences of the bidding public, and to identify apparent factors other than grade affecting bidding prices of the audience.

\section{Literature cited}

Duncan, S.L.S. 1996. Cognitive apprenticeship in classroom instruction: Implications for industrial and technical teacher education. J. Ind. Teach. Educ. 33(3): 66-86.

Mexal, J.G., D.J. Cotter, and A. Palormo. 2004. Seed Money: Helping our students grow: A model for giving. North Amer. Colleges Teachers Agr. J. 48(1):2-6.

Nefstead, W.E. 2001. Developing a retail management course: A case study of ApEc3821. 25 May 2011. <http:// ageconsearch.umn.edu/bitstream/20479/ 1/sp01ne01.pdfs.

Newcomb, L.H., J.D. McCracken, J.R. Warmbrod, and M.S. Wittington. 2004. Methods of teaching agriculture. 3rd ed. Pearson-Prentice Hall, Upper Saddle River, NJ. 